\title{
FISCALITAT LOCAL I DEUTE PÚBLIC AL PAÍS VALENCIÀ. L'ADMI- NISTRACIÓ DE LA VILA DE BORRIANA A MITJAN SEGLE XV
}

\author{
PAU VICIANO
}

\section{SUMARI}

1. La fiscalitat municipal: una pressió sobre el patrimoni. - 2. La gestió fiscal: protagonistes i factors econòmics. - 3. La despesa pública. - 4. L'endeutament censalista. - 5. La política de sanejament i el seu cost social. - 6. De l'endeutament públic a la dependència política.

Ja fa temps que la imatge daurada del Quatrecents valencià, bastida sobretot a partir de la puixança de la capital, ha estat seriosament matisada, fins al punt de remarcar-se que les sumes posades al servei de la corona per la ciutat no sols eren mostra d'una gran capacitat fiscal, sinó que tenien com a contrapunt un enorme endeutament públic que minava l'aparent solidesa de les seues finances '. El cas de la ciutat de València no era únic. Les viles que s'escampaven per les comarques rurals també disposaven d'ingressos fiscals importants, però l'economia d'aquests municipis tenia poc a veure amb les lluïssors que irradiava el cap i casal del regne.

En 1450 el cavaller Joan Torrelles, clavari de la vila de Borriana, tancava la seua recaptació anual a mb uns ingressos que oscil · laven a l'entorn dels 22.000 sous. A la mateixa època, Pere Ferrando, el lloctinent del batlle reial, només n'aconseguia uns 6.000 per als cofres de la corona ${ }^{2}$ El municipi no sols comptava amb instruments fiscals més poderosos que la batllia local, sinó que els gestionava de manera més eficaç. Això no volia dir, però, que les finances 1976.

' Ernest Belenguer CebriÀ, València en la crisi del segle XV, Barcelona, Edicions 62,

2 En el període 1450-1454 les rendes de la batllia de Borriana assoliren una mitjana anual de 6.125 sous, ARV, Mestre Racional, 1.952. 
veïnals estiguessen sanejades. Tot al contrari, la vila s'havia vist forçada a un endeutament crònic que a mitjan segle XV havia provocat el col · lapse de la seua hisenda, fins al punt que per a fer cara al pagament dels interessos i tornar una part dels capitals havia hagut de recórrer a l'ajut de la corona.

Joan Torrelles, en nom de la universitat, havia rebut així del batlle general de València, el cavaller Berenguer Mercader, la suma de 14.000 sous "per obs de fer certs quitaments» que permetessen alleugerir el pes del deute. Aquesta assistència exigia les seues contrapartides. Durant una dècada, si més no, el municipi va perdre bona part de la seua autonomia financera, ja que els comptes de la gestió del clavari no sols foren supervisats pels prohoms locals, sinó que en última instància requeriren l'aprovació d'un òrgan central del poder reial com era el mestre racional. Gràcies a aquest control de l'administració de la corona s' han conservat a l'Arxiu del Regne de València els quaderns de comptes del clavari de Borriana del període 1449-1458 ', en contrast amb l'absència de documentació medieval que presenta avui el seu arxiu municipal, i podem endinsar-nos així en la gestió de les finances d'aquest municipi de reialenc.

\section{LA FISCALITAT MUNICIPAL: UNA PRESSIÓ SOBRE EL PATRIMONI}

La Borriana de mitjan segle XV estava molt lluny de ser la important vila que, des de la conquista de Jaume I, havia esdevingut el centre de la plana a la qual havia donat nom. En 1451, en una època de recessió demogràfica de tot el nord del regne, només comptava amb una població de 264 focs, mentre que Vila-real i Onda en tenien 364 i 397 respectivament i Castelló resistia com a nucli principal de la comarca amb 649 focs ${ }^{4}$. Amb unes dimensions tan reduïdes -i que encara minvarien durant la resta de la centúria- Borriana i les altres viles de la Plana tenien uns trets més aviat rurals. I de fet, la majoria dels seus veïns eren llauradors, encara que convivien amb alguns artesans $i$ un grapat de mercaders $i$ professionals liberals. Fins $i$ tot hi havia a una reduïda nòmina de donzells $\mathrm{i}$ cavallers, que sobretot a Borriana, al costat dels delegats de l'orde de Montesa ', eren titulars de les petites alqueries que clapejaven el terme d'aquesta població reial.

3 ARV, Mestre Racional, 10.346-10.349 (Claveria de Borriana, 1449-1458).

${ }^{4}$ Es tracta de fogatges fiscals avaluats per a la recaptació del morabatí, segons el minuciós treball d'Enric GUINOT RODRÍGUEZ, Demografia medieval del nord del País Valencià, en «Estudis sobre la població del País Valencià», València, Universitat, 1988, pp. 229-249.

'L'orde de Montesa pagava 200 sous de cena a la batllia local en reconeixement de les 
El veïnat de la vila -inclosos els jueus de la seua aljama- pagava al municipi per diversos conceptes fiscals, però a mitjan segle XV la peita $i$ les cises, amb un $90 \%$ dels ingressos globals, eren les seues principals fonts de finançament ${ }^{6}$. La peita constituïa un impost directe que gravava -com la talla al Principat- el patrimoni dels veïns i forasters heretats al terme de la vila. En un principi havia estat una renda de la corona, però ja a la primera meitat del segle XIV la recaptació va ser cedida als municipis, que havien de lliurar a la batllia reial una quantitat que romangué fixa per a la resta de l'Edat Mitjana. Així, les autoritats de la vila podien extraure uns 16.000 sous per aquest impost, mentre que sols n'havien de pagar al batlle local 2.000. Aquesta diferència convertia la peita en l'ingrés fonamental de la universitat de Borriana, ja que amb uns 16.000 sous de recaptació aportava les tres quartes parts dels recursos que gestionaven els prohoms locals.

\section{Quadre 1}

Ingressos municipals*

\begin{tabular}{|c|c|c|c|c|c|c|}
\hline & $1449-50$ & $1450-51$ & $1451-52$ & $1454-55$ & $1455-56$ & total \\
\hline peita & $16.634 / 4$ & $16.269 / 6$ & $15.708 / 8$ & $16.279 / 3$ & $15.958 / 1$ & $80.849 / 10$ \\
\hline cises & 3.200 & 3.200 & 2.805 & 3.700 & 3.600 & 16.505 \\
\hline primícia & 2.300 & 2.200 & 1.800 & 1.600 & 1.800 & 9.700 \\
\hline vuitenes & 300 & 300 & 150 & 200 & 220 & 1.170 \\
\hline herbatge & 281 & $100 / 3$ & 181 & & & $562 / 3$ \\
\hline TOTAL & $22.715 / 4$ & $22.069 / 9$ & $20.644 / 8$ & $21.779 / 3$ & $21.578 / 1$ & $108.787 / 1$ \\
\hline
\end{tabular}

* Totes les quantitats en sous/diners

D'entrada, la peita era un impost proporcional al valor dels béns que cada contribuent tenia assignat en el padró de riquesa municipal. Sobre aquesta base imponible, el govern local aplicava una taxa -variable segons les necessitats pecuniàries del moment- que determinava la suma concreta que devia pagar cadascú. El caràcter proporcional de l'impost, tanmateix, tenia els seus límits. No coneixem els criteris concrets que se seguien a Borriana per a avaluar la riquesa fiscal dels veïns, però les dades referents a viles properes com Castelló

seues possessions a Borriana. Pel que fa als titulars de les alqueries al segle XIII, pot veure's el recull de cartes de població d'Enric GUINOT RODRÍGUEZ, Cartes de poblament medievals valencianes, València, Generalitat, 1991.

- Es tracta dels ingressos ordinaris recollits al quadre 1, que no inclouen els retards de recaptacions anteriors ni les entrades extraordinàries com el préstec del batlle general. 
fan pensar que bàsicament es gravava la terra i els immobles urbans, mentre que el ramat i sobretot els capitals destinats al comerç o al crèdit -propietat del sector dominant de la comunitat-podien eludir en bona mesura la càrrega impositiva . D'altra banda, els cavallers i donzells que senyorejaven les petites alqueries del terme pugnaven per veure's enfranquits d'aquest impost que requeia sobre les seues terres. Això originava nombrosos conflictes amb les autoritats municipals, tal com succeïa en 1455 , quan un delegat de la vila hagué d'anar a València "per la qüestió dels fermes de dret e recorsos" referents al plet contra Jaume Manuel, el senyor del lloc de Carabona, per "rahó de les peytes". "'

Les cises-anomenades també imposicions- eren un impost reial que la corona havia cedit als municipis des de la segona meitat del Trescents. Tenien un caràcter indirecte $i$ afectaven sobretot la venda i la transformació d'articles de primera necessitat com el pa, el vi, la carn, els teixits i la moltura de cereals ${ }^{8}$. Aquest impost encaria el preu dels productes de consum bàsics, de manera que eren els sectors socials populars els qui més en sofrien el rigor. Amb tot, a mitjan Quatrecents el seu pes en les finances municipals no era tan important com en altres viles de la Plana: els tres milers de sous que es recaptaven venien a suposar un $15 \%$ dels ingressos, quan en altres llocs de la comarca s'equiparaven a la peita".

Sobre l'origen i la col-lecta de la peita municipal pot veure's l'article de José SÁNCHEZ ADELL, Estructura agraria de Castellón de la Plana en 1398, "Saitabi», XXIII (1973), pp. 147-175. En aquest «llibre de vàlues» més del $90 \%$ de la riquesa imponible eren propietats immobles -només la terra representava ja el $65 \%-$, mentre que els béns mobles no arribaven a la desena part -els ramats suposaven sols el $2 \%-$, i això, encara que Castelló era una vila més agrícola que les poblacions llaneres del Maestrat, indica que la riquesa moble dels contribuents estava poc gravada per la peita.

ths ARV, Mestre Racional, 10.348.

${ }^{8}$ Per a la comarca de la Plana disposem d'una descripció detallada dels productes gravats i de les taxes que s'aplicaven a Onda, gràcies a la documentació publicada per Carlos FRADEJAS i Piedad GARCIA, El régimen municipal de Onda a mediados del siglo XV, "Centre d'Estudis d'Onda", 2 (1989), pp. 10-87. L'abast de les cises era semblant en altres viles valencianes, segons els treballs d'Antoni FURIÓ i Ferran GARCÍA, La economía municipal de Alzira a fines del siglo XIV según un libro de cuentas de 1380-1381, en «La ciudad hispánica durante los siglos XIII al XVIn, Madrid, Universidad Complutense, 1985, pp. 1.611-1.633, i de Manuel V. FEBRER, Crisis económica y conflictos feudales en la encomienda de Torrent durante la segunda mitad del siglo XIV, «Torrens», 5 (Torrent, 1986-1987), pp. 41-98.

"Vers 1425 les cises representaven un $54 \%$ dels ingressos de la vila de Castelló, segons Pau VICIANO, Ingrés $i$ despesa d'una vila valenciana del Quatrecents. Les finances municipals de Castelló de la Plana (1426-1427), "Boletín de la Sociedad Castellonense de Cultura», LXVI (1990), pp. 635-664. A Vila-real assolien un $25 \%$ de les rendes ordinàries a mitjan segle XIV, d'acord amb Àngels de Beltran, L'economia municipal de Vila-real en 1362-1363, segons un llibre de claveria, en "I Congrés d'Història i Filologia de la Plana», Nules, Ajuntament, 1990, pp. 131-139. 
A banda dels dos impostos fonamentals, la universitat de Borriana disposava d'altres ingressos remarcables. La primícia, una renda d'origen eclesiàstic sobre les collites del terme, havia estat lliurada per Martí I a la vila en $1403^{\text {" }, \text { i }}$ amb una mitjana d'uns 2.000 sous anuals s'acostava a la desena part dels recursos municipals. Menys importància econòmica tenien l'berbatge, una imposició de caràcter ramader ", i les vuitenes e vaguants, ja que en conjunt no arribaven al mig miler de sous per any.

Els ingressos municipals, doncs, eren sobretot directes -les tres quartes parts provenien de la peita- $\mathrm{i}$ requeien en un $85 \%$ sobre la riquesa agrària, en la mesura que la peita es carregava sobre la possessió de la terra, les primícies sobre les collites i l'herbatge afectava la ramaderia. En canvi les entrades indirectes que es nodrien del consum i del comerç local -les cises- tenien un paper molt secundari, que a penes arribava a la sisena part dels ingressos de la vila.

\section{LA GESTIÓ FISCAL: PROTAGONISTES I FACTORS ECONÒMICS}

El responsable de la gestió fiscal del municipi era el clavari i en última instància els jurats, per bé que aquests oficials no s'encarregaven personalment de redactar la comptabilitat, que restava en mans de l'escrivà, ni d'efectuar les col-lectes, que normalment s'encarregaven a particulars assalariats o arrendataris. Així, la recaptació de la peita era encomanada per la vila a aquell veí que es comprometés a efectuar-la a canvi d'un salari menor. Per a evitar riscs que poguessen amenaçar la solvència de les finances públiques, el municipi exigia als peiters unes sòlides garanties, que es palesaven en el valor del seu patrimoni personal i en els fiadors que havien de presentar. La recaptació d'un impost tan exhaustiu exigia unes habilitats comptables i una dedicació que eren retribuïdes amb un generós salari de 1.000 sous, molt més elevat que el que cobraven els jurats, els principals responsables del govern local.

Si el salari fix dels peiters era atractiu per als prohoms de Borriana, la recaptació de les imposicions que s'arrendaven encara oferia la possibilitat d'un negoci més lucratiu a aquells veïns que disposaven de capitals líquids. L'arrendament era una operació més especulativa que la col·lecta assalariada i això

10 Francisco Roca y AlCAIDE, Historia de Burriana, Castelló, 1932, p. 244.

"L'herbatge era el dret que es pagava per a pasturar en el terme d'un lloc i normalment pertanyia a la senyoria, tal com passava al nord del país, vegeu, d'Enric GUINOT, Feudalismo en expansión en el norte valenciano. Antecedentes y desarrollo del señorio de la Orden de Montesa. Siglos XIII y XIV, Castelló, Diputació, 1986, pp. 207- 211. 
volia dir que s'havien d'assumir més riscs com males'collites i epidèmies que podien afonar les recaptacions i abocar els arrendataris a l'incompliment del contracte i a l'embargament per part del municipi. Però també és cert que les possibilitats de guany eren més atractives: la diferència entre les sumes que s'avançaven a la vila i els ingressos que realment recaptaven els arrendataris solia ser substanciosa en el cas de les primícies i vuitenes, i sobretot de les cises. La vila es desentenia així d'una recaptació que hauria estat difícil d'efectuar amb personal assalariat $\mathrm{i}$ al mateix temps obria la porta a un negoci que beneficiava uns inversors privats que es reclutaven en el mateix medi social que els dirigents municipals. Així succeïa en un vila propera com Castelló, on eren sobretot els mercaders locals que participaven en el poder municipal, coneixedors del joc del mercat i ben fornits de moneda, els qui controlaven l'arrendament de les cises. La situació no era diferent a Borriana, on a pesar de les poques dades disponibles pot afirmar-se que l'arrendament dels impostos municipals també estava en mans de l'oligarquia local. D'aquesta manera, a mitjan segle XV un personatge com Joan de Vera arrendava les cises en 1450-1451 i l'any següent, mentre que en 1454-1455 recaptava les vuitenes. Al seu torn, el també borrianenc Rafael Tarragó va arrendar aquest impost en el següent exercici i ja en 1448-1449 s'havia encarregat de la col-lecta de la primícia. Joan Martí, un prohom que havia ocupat sovint el càrrec de jutge comptador del municipi, invertí els seus capitals en l'arrendament de les cises en 1454-1455 i de la primícia en aquest mateix període i en 1455-1456. Les seues activitats, però, no es reduïen a l'àmbit municipal, perquè en $1450 \mathrm{i}$ en 1451 recaptà també el terç delme de la batllia. Sens dubte es tractava de personatges benestants de la comunitat, ja que les sumes que s'arriscaven en els contractres ben sovint superaven el miler de sous: només el muntant dels arrendaments signats per Joan Martí en 1454 ja ascendia a 5.300 sous.

\section{Quadre 2 \\ Arrendataris (1449-1456)}

Miquel Asterç (Borriana)

Berenguer Busquet (Borriana)

Joan Calbet

Francesc Castelló (notari)

Joan Egual (Borriana)

Domingo Jaquès

Joan Martí (Borriana) cises $1455-1456$

vuitenes $1449-1450,1450-1451$

primícia 1449-1450

primícia 1451-1452

cises 1448-1449, 1455-1456

vuitenes $1450-1451$

$\left\{\begin{array}{l}\text { terç delme 1450,1451 } \\ \text { cises 1454-1455 } \\ \text { primícia 1454-1455, 1455-1456 }\end{array}\right.$ 
Andreu Matoses

Guillem Segura

Andreu Serra

Mateu Súnyer

Rafael Tarragó (Borriana)

Joan de Vera (Borriana) cises $1449-1450$

primícia 1450-1451

vuitenes $1451-1452$

primícia 1455-1456

\{ primícia 1448-1449

vuitenes $1455-1456$

$\left\{\begin{array}{l}\text { cises } 1450-1451,1451-1452 \\ \text { vuitenes } 1454-1455\end{array}\right.$

Les xarxes fiscals que havia desplegat el municipi gravaven sobretot l'activitat econòmica del veïnat de Borriana, de manera que la fluctuació dels seus ingressos depenia, en primer lloc, de la riquesa agrícola i del volum d'intercanvis comercials. En efecte, l'extensió i la valoració de les terres del terme determinaven la base imponible de la peita, mentre que el terç delme i les primícies reflectien les oscil -lacions de les collites. Al seu torn, la vitalitat del mercat local -sobretot de productes de consum-condicionava les recaptacions de les cises. No cal caure en plantejaments «neomalthusians» per a considerar que aquests grans factors econòmics -superfície cultivada, producció agrària bruta $\mathrm{i}$ volum de consum- anaven estretament vinculats a la demografia, fins al punt que els nivells de població de la vila són un bon índex de la seua conjuntura econòmica. En aquest sentit, el panorama de la comarca de la Plana va ser clarament depressiu durant el segle XV i Borriana no en fou cap excepció. Aquesta vila havia passat d'uns 350 focs en 1427 a uns 260 en 1451 , una davallada que no tocaria fons fins a ensorrar-se en un centenar de focs en 1487. La reducció dels efectius demogràfics -d'un $70 \%$ al llarg del Quatrecents- havia d'afectar per força el nivell dels ingressos municipals. Era aquesta atonia demogràfica, en definitiva, la que explica el reduit muntant d'unes imposicions que, com les cises, gravaven les compra-vendes de productes de primera necessitat. De la mateixa manera, la baixada de la producció agrària afonava els ingressos del terç delme, una de les rendes claus de la batllia local, però, a diferència dels administradors reials -lligats de peus $\mathrm{i}$ mans davant el declivi de les recaptacions-, el consell de la vila disposava de mecanismes per a compensar la caiguda de les cises. La solució era incrementar els ingressos de la peita amb una major pressió sobre els immobles -terra i cases- radicats en la vila $i$ el seu terme. Aquesta solució de redreç era especialment costosa per a la majoria d'un veïnat format per llauradors i el que cal preguntar-se és si l'esforç impositiu que se'ls exigia estava justificat. En altres paraules, $s$ 'ha de conèixer on anaven a parar els diners que gestionaven els jurats. 


\section{LA DESPESA PÚBLICA}

Si hi ha alguna cosa clara és que els impostos no tornaven als contribuents en forma de serveis. El pressupost municipal de Borriana entre 1449-1456, en ple procés de sanejament econòmic, va ser d'una austeritat esfereïdora pel que feia a les inversions d'interès comunitari. En cinc anys la suma global d'aquest capítol no arribà als dos milers de sous i això volia dir que els recursos destinats a cobrir les necessitats del veïnat a penes superaren l'1 \% de la despesa pública ${ }^{\prime 2}$. La meitat d'aquests diners s'esmerçaren en serveis religiosos -frares predicadors i cera per a l'església- $\mathrm{i}$ més de la quarta part en l'adquisició d'armes per a la vila. A banda dels 350 sous que es van despendre en forment "per ops del forniment de la dita vila» i del mig centenar per a la cura dels pous, el capítol assistencial i de manteniment de les infrastructures -camins, xarxa de reg- va ser completament nul. Les exigències de la política d'ajust, sens dubte, expliquen aquesta penúria, però cal no oblidar que en situacions més normals -el municipi medieval no era precisament el welfare state- la inversió comunitària de llocs com Vila-real, Alzira o Castelló es trobava al voltant del $5 \%$ de la despesa ".

\section{Quadre 3 \\ Despesa municipal}

\begin{tabular}{|c|c|c|c|c|c|c|}
\hline & $1449-50$ & $1450-51$ & $1451-52$ & $1454-55$ & $1455-56$ & total \\
\hline omunitari & 130 & 200 & 240 & 347 & $876 / 2$ & $1.793 / 2$ \\
\hline & $4.229 / 9$ & $3.979 / 10$ & $3.644 / 8$ & 3.229 & & $53 / 3$ \\
\hline & 2.700 & 2.700 & 2.700 & 2.700 & 2.700 & 13.500 \\
\hline 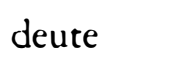 & $30.266 / 2$ & $16.957 / 6$ & $16.731 / 6$ & 16.25 & $15.831 / 11$ & $96.044 / 11$ \\
\hline )TAL & $37.325 / 11$ & $23.837 / 4$ & $23.316 / 2$ & $22.533 / 10$ & $21.578 / 1$ & $128.591 / 4$ \\
\hline
\end{tabular}

La política d'ajust no havia estat tan decidida quan es tractà de tocar les retribucions dels oficials que gestionaven el poder municipal. En efecte, la despesa burocràtica, que incloïa a més dels salaris uns altres conceptes com les dietes o la redacció de documents, s'enduia un $13 \%$ de les eixides, una proporció que lluny de ser reduïda era igual o superior a la d'altres viles de la

1. Les dades sobre la despesa recollides al quadre 3 s'han d'avaluar en relació als ingressos comptables, que a més de les entrades teòriques del quadre 1 , inclö̈en els 14.000 sous del préstec reial i diverses quantitats en concepte de retards i restes d'exercicis anteriors.

"Vegeu les notes 8 i 9. 
Plana. I eren els dirigents locals i el personal qualificat que s'encarregava de l'administració econòmica i de l'assessorament jurídic els principals beneficiaris d'aquest capítol, ja que els 3.000 sous que rebien cada any en termes mitjans suposaven el $80 \%$ de les despeses burocràtiques. El funcionari millor pagat, el responsable tècnic de la hisenda local, era el clavari amb 1.100 sous anuals, seguit del peiter, que en rebia un miler com a paga per la recaptació dels ingressos fonamentals de la vila. La resta dels salaris ja estaven molt per sota: 150 sous cobrava l'escrivà dels jurats $\mathrm{i}$ el funcionari del mestre racional que supervisava els comptes del clavari, mentre que els quatre advocats que la vila tenia a València ingressaven un centenar de sous cadascun. Finalment, els jurats -també quatre- eren els que tenien una retribució menor, a pesar que exercien la gestió política del municipi. El salari dels jurats -50 sous-era més reduït que el de personal subaltern com els guardians del terme, $i$ en el cas dels consellers era inexistent. La compensació econòmica, doncs, no devia ser allò que motivava els prohoms locals a ocupar els càrrecs públics, sinó més aviat la possibilitat de gestionar el poder d'acord amb els seus interessos de grup, especialment en una època tan difícil com la que travessava la vila.

No pot dir-se que les obligacions que el municipi tenia envers la batllia reial fossen massa pesades. Només s'invertia una desena part de la despesa de Borriana -2.700 sous a l'any- en el pagament de la peita i la cena. Ara bé, a banda d'aquestes rendes ordinàries la corona i les corts solien efectuar demandes pecuniàries que podien agreujar significativament les càrregues veïnals. Durant 1449-1456 no es registrà en els comptes de la vila cap lliurament extraordinari, però se n'havia efectuat un, poc abans, que encara no s'havia acabat de pagar, ja que en 1449 la governació feia gestions «per executar la resta del repartiment dels donatius de les corts del senyor rey de Navarra últimament celebrades». Amb tot, els principals maldecaps de les autoritats comunals no eren satisfer les rendes de la corona sinó fer cara a l'aclaparador endeutament de la vila.

\section{L'ENDEUTAMENT CENSALISTA}

Mal punt hi són entrats per a obs de la gent, que tot lo món han destroït, e la mar e la terra... ja les comunitats no poden suportar los càrrechs dels censals. Los singulars tots quasi són endeutats e empobrits a cens ${ }^{14}$.

14 Citat per Miguel Llop CATALÀ, Observaciones socio-económicas en la predicación de san Vicente Ferrer, "Escritos del Vedat», XVIII (València, 1988), p. 237. 
Així denunciava sant Vicent Ferrer en les seues enceses predicacions els efectes negatius del censal, una forma de crèdit que des de la segona meitat del Trescents havia anat introduint-se tant en les economies privades com en les públiques. Cap a 1410, sermons com aquest palesaven els estralls que ja provocava l'espiral censalista en les finances de nombroses viles valencianes. Quaranta anys després li tocava el torn a Borriana. En efecte, el volum del deute era tan aclaparador que en l'exercici de 1449-1450 s' havien de destinar a pagar els interessos -les pensions dels censals- quasi 10.000 sous, una xifra que representava més del $40 \%$ dels ingressos fiscals ordinaris del municipi.

Aquesta situació no va variar molt durant la resta del període, ja que de cada deu sous que es van despendre en 1449- 1456 més de tres es destinaren a satisfer les pensions. Una suma semblant -més de 40.000 sous- es va invertir en el quitament d'alguns censals i les eixides restants foren la devolució dels 14.000 sous prestats pel batlle general per a iniciar el sanejament del municipi. En conjunt, doncs, els pagaments que va generar l'endeutament públic suposaren un $75 \%$ de la despesa de la vila.

Quadre 4

Endeutament públic

\begin{tabular}{|c|c|c|c|c|c|c|}
\hline & $1449-50$ & $1450-51$ & $1451-52$ & $1454-55$ & $1455-56$ & total \\
\hline & $9.566 / 2$ & $9.957 / 6$ & $9.481 / 6$ & $6.480 / 2$ & $5.925 / 6$ & 41.41 \\
\hline & 13.700 & & 7.250 & {$[9.777 / 8]^{*}$} & {$[9.906 / 5]^{*}$} & $40.634 / 1$ \\
\hline & 7.000 & 7.000 & & & & 14.000 \\
\hline & $30.266 / 2$ & $16.957 / 6$ & $16.731 / 6$ & $16.257 / 10$ & $15.831 / 11$ & $96.044 / 11$ \\
\hline
\end{tabular}

* Vegeu la nota 24.

El flux pecuniari que eixia de la caixa municipal en forma de pensions censalistes anava a beneficiar sobretot creditors forasters: en cinc anys els rèdits cobrats per veïns de la vila a penes van superar el miler de sous, és a dir, menys del $3 \%$ d'aquests pagaments. Els diners, com els homes i les dones, fugien cap a la ciutat. València, l'única població del país amb una veritable entitat urbana,

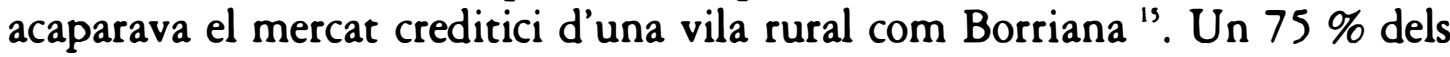

is L'hegemonia dels censalistes de València era també clara a Castelló en 1426-1427, on controlaven més del $75 \%$ de les pensions i deixaven la resta als creditors locals, mentre que a Onda el seu domini encara s'incrementava al $80 \%$ dels rèdits en 1458-1459-vegeu les notes 8 i 9-. Aquest control del mercat creditici per part dels censalistes urbans també s'evidencia a la comarca de la Ribera del Xúquer, segons Antoni FURIÓ, Crédito y endeudamiento: el censal en la sociedad rural valenciana (siglos XIV-XV) en "Señorío y feudalismo en la península ibérica (siglos XII-XIX)», (Saragossa, 1989), en premsa. 
41.000 sous satisfets en 1449-1456 havien anat a engrossir les bosses de censalistes residents a València. Només la principal població de la comarca, Castelló, tenia una presència apreciable, tot i que molt allunyada de la capital del regne, en la mesura que absorbia un $7 \%$ dels interessos. La resta de viles -totes properes com Nules i Morvedre- en conjunt encara tenien un paper menys rellevant $i$, ja fora dels nuclis de població, el monestir rural de Portaceli, enclavat a $25 \mathrm{~km}$ al nord de la capital, va ingressar una suma lleugerament superior a la que afluí cap a Castelló. Vist en perspectiva, aquesta hegemonia de València tendí a consolidar-se a mesura que es produïen els quitaments, ja que els creditors castellonencs recuperaren tots els seus capitals i els de Borriana i de la resta de viles veieren reduïdes dràsticament les pensions que cobraven gràcies a la política de sanejament municipal. D'aquesta manera, malgrat la disminució del volum de les pensions, els censalistes de la capital passaren de controlar poc menys del $70 \%$ de les rendes en 1449-1450 a percebre'n quasi el $90 \%$ en $1455-1456$.

\section{Quadre 5 \\ Pensions censalistes}

$\begin{array}{lccccccc} & 1449-50 & 1450-51 & & 1451-52 & 1454-55 & 1455-56 & \text { total } \\ \text { València } & 6.551 / 2 & 6.942 / 6 & 6.496 / 6 & 5.755 / 2 & 5.200 / 6 & 30.945 / 10 \\ \text { Castelló } & 1.000 & 1.000 & 1.000 & & & 3.000 \\ \text { Borriana } & 290 & 290 & 360 & 125 & 125 & 1.190 \\ \text { altres } & 1.725 & 1.725 & 1.625 & 600 & 600 & 6.275 \\ \text { TOTAL } & 9.566 / 2 & 9.957 / 6 & 9.481 / 6 & 6.480 / 2 & 5.925 / 6 & 41.410 / 40\end{array}$

El mercat del crèdit censalista, doncs, estava ben articulat al voltant de la ciutat de València, si més no pel que feia al deute públic, que requeria l'aportació de capitals molt més elevats que les modestes sumes -inferiors al mig miler de sous- que els llauradors $\mathrm{i}$ artesans podien manllevar dels seus veìns acomodats ${ }^{16}$. En canvi, per a fer cara a les necessitats de la "cosa pública» calia posar en circulació capitals que es comptaven per milers de sous, i aquests només podien eixir dels sectors enriquits que habitaven el medi urbà i algunes viles importants de la comarca com Castelló. En efecte, el volum mitjà dels capitals que es quitaren superava els tres milers de sous, amb uns valors

${ }^{16}$ Sobre el mercat del crèdit privat en un àmbit rural pot veure's el treball col lectiu d'A. Furió, J. V. García Marsilla, A. J. Mira, S. Verger i P. Viciano, Endeutament i morositat en una comunitat rural. El censal a Sueca a finals del segle XV, en "V Assemblea d'Història de la Ribera», (Almussafes, 1988), en premsa. 
extrems que anaven de 1.000 a 7.000 sous. I, de fet, els qui disposaven d'aquests diners líquids per a invertir en el préstec eren burgesos rics i aristòcrates assentats sobretot a la ciutat de València. Més de la meitat de les pensions que Borriana va pagar en 1449-1456 anaren a parar a mans de professionals urbans -sobretot notaris $i$ juristes- $i$ una cinquena part se l'embossaren donzells i cavallers. En conjunt, aquest sector dominant representava poc més del $60 \%$ dels censalistes, però s'endugué les tres quartes parts de les pensions. Menor era la participació d'eclesiàstics -malgrat el pes d'alguna institució monàstica- $\mathrm{i}$ d'artesans acomodats, que sols acumularen un cinquè dels rèdits ".

\section{Quadre 6 \\ Nivell social dels creditors}

\begin{tabular}{lcc} 
& censalistes & pensions \\
\cline { 2 - 3 } burgesos & 20 & $21.871 / 8$ \\
nobles & 11 & $8.845 / 8$ \\
eclesiàstics & 5 & $5.337 / 6$ \\
artesans & 4 & 3.236 \\
desconegut & 9 & 2.120 \\
TOTAL & 49 & $41.410 / 10$
\end{tabular}

Així, entre els censalistes que en els cinc anys coneguts cobraren més de 3.000 sous en pensions destacava el ciutadà Jaume Julià amb $3.875^{18}$, seguit pel monestir de Portaceli amb 3.500 i per Elionor Saera, viuda del ciutadà Bernat Suau, que en rebé més de 3.160. Margarida, viuda del notari Lluís Gaçó, va ingressar 2.000 sous durant aquest període i, entre aquesta suma i els 1.500 , es trobaven els donzells Joan Ros d'Orsins i Pere Saranyó i el pintor Manuel Llopis. A excepció del monestir, tots aquests destacats creditors residien a la ciutat de València $i$, de fet, l'hegemonia d'aquest centre urbà es confirma si considerem que només dos creditors de la resta del país -ambdós de la Plana- tenien un pes comparable: el notari Francesc Castelló, de Nules, i el

17 Els burgesos eren 7 notaris, 5 ciutadans, 4 juristes, 3 mercaders i un draper. Els aristòcrates eren 6 donzells, 3 cavallers i 2 nobles. Els eclesiàstics comprenien el monestir de Portaceli, la seu de València i 3 preveres. Els artesans eren 2 pintors, un botiguer $i$ un pellisser.

${ }^{18}$ S'hi afegien dos membres més del llinatge -el ciutadà Pere i el cavaller Miquelque, en conjunt, cobraren més de 1.800 sous en pensions. Per altra banda, Miquel Julià també rebia 1.500 sous anuals de rèdits de la vila de Castelló en 1426-1427. 
mercader castellonenc Miquel Arrufat, que cobraren 1.800 i 1.575 sous respectivament.

Les autoritats de Borriana, doncs, no havien hagut d'anar gaire lluny per a trobar els creditors que necessitaven. En la mateixa comarca i sobretot en la poderosa capital del regne - en qualsevol cas a menys de $60 \mathrm{~km}$ - hi havia rendistes disposats a invertir els seus capitals. Ben netejat de les inicials connotacions usuràries, el censal oferia a un sector de la cavalleria urbana uns ingressos complementaris de la renda feudal dels seus esquifits dominis ", de la mateixa manera que mercaders i professionals hi buscaven una inversió segura davant les oscil-lacions dels seus guanys " Borriana- el crèdit censalista constituiia una mena de pensió de viduïtat "i fins $i$ tot institucions eclesiàstiques com la cartoixa de Portaceli i la seu de València no menyspreaven aquesta forma de rendisme que se superposava als seus ingressos territorials ${ }^{22}$. Diverses actituds rendistes que, al capdavall, es beneficiaven de la veritable sagnia de recursos que sofria la vila, una situació que a mitjan segle XV es va mostrar insostenible si no s'emprenia una política de sanejament.

\section{LA POLÍTICA DE SANEJAMENT I EL SEU COST SOCIAL}

Amb una càrrega censalista que obligava a despendre uns 9.500 sous

19 I no era estrany que les rendes censalistes superassen els ingressos de les petites senyories que detentaven aquests cavallers en l'Horta de València, vegeu la síntesi d'A. FURIÓ, Crédito y endeudamiento..., op. cit.

${ }^{20}$ La participació dels patricis de València en el deute públic de la ciutat $\mathrm{i}$ de les viles del regne ha estat estudiada per Rafael NARBONA VizCAínO, Gobierno político y lucbas sociales. Estrategias de poder del patriciado urbano. La ciudad de Valencia (13561419), València, Universitat, 1989, tesi doctoral inèdita. Un cas representatiu de la importància de la inversió censalista, superior a l'adquisició de terres, és el del mercader Joan Amalric, segons Pau VICIANO, L'estratègia rendista del patriciat valencià: el censal $i$ la terra en les inversions d'un mercader del segle XV, "Afers», 11-12 (València, 1991), pp. 127-136.

${ }^{21}$ Sobre les inversions efectuades per les dones de la ciutat, Paulino IRADIEL, «Familia y función económica de la mujer en actividades no agrarias", en La condición de la mujer en la Edad Media, Madrid, Universidad Complutense, 1986, pp. 223-259.

22 Un clar exemple de l'ascens de les inversions censalistes en les economies monàstiques és el de la Saïdia de València, amb uns ingressos que vers 1495 depenien en un $40 \%$ de les pensions i només en un $30 \%$ dels censos emfitèutics; vegeu el treball de Pau VicianO, La gestió econòmica d'un monestir cistercenc femeni: la Saïdia de València a la fi del segle XV, «Revista d'Història Medieval», 2 (València, 1991), pp. 111-132. 
anuals en pensions $\mathrm{i}$ una riquesa decreixent durant el segle XV -si atenem la gravetat del seu descens demogràfic-, la vila de Borriana ho tenia cada volta més difícil per a fer cara als interessos que puntualment li exigien els creditors. L'espectre de la insolvència ja s'havia deixat veure des de 1440 . No eren pocs els censalistes que a final d'aquesta dècada, en iniciar-se la política d'ajust, reclamaven pensions que el municipi els devia des de feia anys. En efecte, dels sis creditors que recobraren els capitals en 1449, cinc remarcaven que la vila els devia diverses anualitats. El cas més escandalós era el d'Isabel Roca i les seues filles, una viuda d'un notari que havia estat nou anys sense cobrar les pensions. Pere Vilanova, un pellisser de València, reclamava en el mateix any 375 sous pels «ròcegues a ell en lo dit nom deguts de dues pagues» de 1441 i 1442, mentre que el notari Galceran Gamiça, en 1450, n'exigia més de 600 per tres pensions de 1440, 1441 i 1444.

La inquietud dels inversors estava ben justificada davant la precarietat de les finances municipals. L'afany de cobrar les pensions amb regularitat havia fet que abans de 1450 una bona nòmina de creditors acceptassen la reducció de les seues pagues, la qual cosa es traduïa en un descens de la taxa d'interès. Era preferible cobrar menys però puntualment que no pas patir la insolvència de la vila i haver d' iniciar els costosos tràmits d'uns embargaments que, al capdavall, no asseguraven tampoc la recuperació dels diners invertits. Així, dels nou censals que es quitaren en 1449-1450 i en 1451-1452 vuit havien estat reduïts d'un interès original situat entre el 6,66 i el $8,33 \%$-amb un predomini dels valors al voltant del $7 \%$ - a només el $5 \%$. Era aquesta taxa la dominant en el moment de tornar-se els capitals, a excepció d'un violari que romangué invariable al 14,28 \%. Però, malgrat la moderació que representava una taxa d'interès del $5 \%$, de les més baixes documentades en aquesta època, l'enorme volum dels capitals manllevats generava unes pensions que abocaven la vila a una insolvència estructural. Cap a 1450 la situació s'havia fet tan insostenible per a les autoritats veïnals $-i$ també per als creditors- que hagué d'intervenir-hi la corona.

El 30 d'abril de 1449, el clavari de Borriana rebia del batlle general del regne 14.000 sous en concepte de préstec per a finançar la reducció del deute públic. En efecte, els diners s' ingressaven «per obs de fer alguns quitaments de censals e violaris que la universitat de la dita vila de Borriana fehia e era tenguda fer cascun any." Eliminar completament el deute hauria estat molt difícil ja que, si considerem que podia elevar-se a més de 150.000 sous ${ }^{23}$, hauria calgut acumular durant set anys tots els ingressos bruts de la vila per

${ }^{23}$ Els 9.500 sous de les pensions pagades en 1449-1450 suposarien un capital situat entre els 135.700 sous -si considerem un interès inicial del $7 \%$ - i els 190.000 -amb un interès reduït al $5 \%$. 
tornar els capitals als creditors. Amb tot, la reducció parcial del deute fou eficaç, ja que va suposar una disminució d'un $40 \%$ de les pensions, que baixaren d'uns 9.500 sous en 1449-1450 a només 5.400 en 1457-1458. En els comptes figuren quitaments per valor de 20.950 sous i se'n poden estimar uns altres que ascendiren a 19.680 per al període $1454-1456^{24}$. En conjunt, doncs, hi hauria constància d'una despesa d'uns 40.600 sous destinats a tornar una part dels censals, però sens dubte la suma global que es va invertir degué ser considerablement major. Caldria afegir-hi els quitaments efectuats en 14521453 i en 1453-1454, dels quals no hi ha rastre documental, però que si jutgem per les dades de l'exercici anterior ascendien a uns 7.250 sous anuals. Així, el volum de capitals reintegrats als censalistes es devia acostar als 55.100 sous durant un període de set anys, amb la consegüent reducció d'uns 3.600 sous de les pensions ${ }^{23}$. A nivell macroeconòmic, doncs, la política de sanejament fou efectiva, ja que permeté reduir el deute públic en un $40 \%$ en un període curt de temps. L'altra cara de la moneda fou el cost que aquest esforç fiscal tingué en les economies domèstiques.

Pot estimar-se que en l'exercici anterior a l'ajust els ingressos fiscals del municipi ascendien a uns 18.800 sous $^{26}$, que es veieren augmentats bruscament a 22.700 en 1449-1450. Així, cada foc de la vila, en termes mitjans, passaria de pagar 71 sous a 86 , i això volia dir un increment de la pressió fiscal superior al $20 \%$. Aquesta taxa d'exacció municipal, que es mantingué durant tot el període de sanejament, triplicava amb escreix la de les rendes de la batllia -uns 23 sous per foc- $\mathrm{i}$ equivalia al preu del forment que una persona adulta consumia en un any i mig ${ }^{27}$. D'aquesta suma global propera als 90 sous per veí, una seixantena era el cost del deute, mentre que abans de la política d'ajust

${ }^{24}$ Es tracta de la diferència entre els ingressos comptables $i$ les despeses conegudes que no són quitaments, ja que en un període de sanejament financer, sens dubte, aquestes sumes netes es devien destinar a la reducció del deute, encara que no figuren als quaderns de comptes conservats.

25 Això indicaria un interés mitjà proper al $6,66 \%$, una taxa freqüent que confirma la versemblança d'aquestes quantitats.

${ }^{26}$ Considerant que no es quità cap censal i extrapolant les dades de 1449-1450, en l'any anterior les recaptacions només havien de satisfer les següents despeses: 2.700 sous de la fiscalitat reial, uns 4.300 per a la burocràcia, 10.200 de pensions -les de 1449-1450 més els 1.245 sous quitats en aquest exercici- $i$ uns 1.000 sous de serveis comunitaris -el $5 \%$ del total, com succeïa en altres viles valencianes.

27 El consum frumentari d'una persona pot estimar-se en 2 cafissos anuals (uns 400 litres), segons Ferran Garcí-Oliver, Terra de feudals. El País Valencià en la tardor de l'Edat Mitjana, València, Alfons el Magnànim, 1991, p. 106. A mitjan segle XV, en la vila veïna de Castelló, el forment es pagava a uns 30 sous per cafís, com pot veure's en les sèries d'wobligacions», AMC, Cort del Justicia (1455). 
fer cara a les pensions només en costava uns $40^{28}$. Així, si abans de 1450 cada família havia de pagar poc més del valor d'un cafís de cereal per a afrontar les pensions, la política de sanejament -pensions i quitaments inclosos- va augmentar aquesta càrrega fins a dos cafissos. Per a les economies domèstiques mitjanes, aquest redreç equivalia a una boca més que alimentar per família i això era un esforç que requeia sobretot damunt les espatlles dels sectors populars, integrats bàsicament per llauradors petits i mitjans. A través de la peita, el principal impost de la vila, aquests veïns veien gravades directament les terres $\mathrm{i}$ les cases que constituien els seus únics béns. Per contra, si bé és cert que els estrats dominants eren afectats pel caràcter proporcional de la peita, cal remarcar que podien eludir en gran mesura la càrrega fiscal perquè aquests mercaders, notaris i llauradors acomodats no sols posseïen terra, sinó que bona part de la seua riquesa estava invertida en el crèdit, el comerç o eren capitals líquids que estaven exempts de l'impost.

En definitiva, el sobreesforç fiscal que va representar la política de sanejament tingué un cost elevat per als sectors més febles del veïnat de Borriana $\mathrm{i}$, sens dubte, contribuí a agreujar l'emigració que retallava la població de la vila, que durant l'època de l'ajust va baixar dels 264 focs de 1451 a només 166 en 1469. Fins i tot els aconseguiments macroeconòmics es veieren limitats ben aviat, ja que la reducció del deute públic difícilment pogué mantenir-se a partir dels anys seixanta, quan la guerra del Principat motivà un increment de les necessitats fiscals de la monarquia. En 1463 Joan II demanà 440.000 sous a repartir entre les viles del regne i en 1469 obtingué un nou ajut militar que fou seguit per altres donatius en 1473 i 1475 . L'ambiciosa política de Ferran II tornà a posar en marxa el mecanisme de la fiscalitat extraordinària, que assolí el nivell més elevat en les corts de 1484-1488 amb una oferta de 2.500 .000 sous a recaptar per fochs o cases ${ }^{29}$. Els donatius de les corts, doncs, es traduïen en noves càrregues fiscals que difícilment podia afrontar la vila de Borriana sense tornar a recórrer a l'endeutament públic, ja que sovint ni tan sols podia fer cara als moderats pagaments ordinaris. En efecte, a principis del segle XVI el municipi encara devia a la batllia reial algunes peites $i$ cenes de la segona meitat del Quatrecents ${ }^{30}$. Així doncs, dues dècades després de tancar-se el programa

${ }^{28}$ En total les pensions $\mathrm{i}$ els quitaments efectuats en els 5 anys compresos entre $1449 \mathrm{i}$ 1456 -vegeu el quadre 4 - ascendiren a uns $\mathbf{8 2 . 0 0 0}$ sous, que suposaven una despesa anual de 62 sous per cadascun dels 264 focs que llavors tenia la vila, mentre que les pensions estimades per a 1448-1449 -vegeu la nota 26-eren uns 10.800 sous, és a dir, uns 40 per veí.

29 Sylvia RomeU, Les Corts valencianes, València, E. Climent, 1985, pp. 132-133.

30 En 1508 Borriana encara devia a la corona 9.995 sous i 2 diners per peites i cenes del període 1439-1486, segons Enrique CRUSELLES, El maestre racional de Valencia. Función 
d'ajust el panorama era ben poc afalagador: la insolvència pública i la davallada de la demografia de la vila i dels seus recursos fiscals. En definitiva, el pes de l'endeutament censalista i les rigoroses polítiques d'ajust contribuïren a deteriorar l'economia del municipi, fins al punt que en 1487 no sols veia reduïda la seua població a un centenar de focs sinó que un $40 \%$ dels veïns s'havien afonat sota el llindar de la pobresa fiscal ".

\section{DE L'ENDEUTAMENT PÚBLIC A LA DEPENDĖNCIA POLÍTICA}

El principal problema que havien d'afrontar Borriana i les altres viles reials de la Plana durant el segle XV fou el d'un endeutament aclaparador. No es tractava d'una situació aillada. Municipis destacats de les comarques centrals com Alzira -ja des de finals del segle XIV-es veien ofegats també pels interessos censalistes i la mateixa capital del regne havia d'afrontar un enorme deute que minava la seua salut financera. Al Principat les coses no eren molt millors. Durant la segona meitat del Trescents els municipis -si ens fixem en els casos de Barcelona i Cervera- havien de destinar un o dos terços de la seua despesa al pagament de les pensions de censals i violaris ${ }^{32}$. Tant al nord com al sud de la Sénia els ingressos fiscals de les viles depenien sobretot de les contribucions indirectes - cises o imposicions- $\mathrm{i}$ de l'impost directe sobre el patrimoni -peita o talla-, de manera que el finançament municipal als Països Catalans coincidia amb el de les viles occitanes, però es diferenciava del model dominant a Castella, basat en l'explotació dels immobles públics i en la fiscalitat indirecta ${ }^{3}$, i del vigent al nord del regne de França, que depenia pràcticament en exclusiva de les taxes ad valorem sobre el consum ${ }^{34}$. Però, malgrat la disparitat

política y desarrollo administrativo del oficio público en el siglo $x V$, València, Alfons el Magnànim, 1989, p. 272.

${ }^{31}$ En 1481, d'un total de 160 focs fiscals, 70 estaven exempts de pagar el morabatía causa de la seua pobresa, és a dir, perquè no posseïen béns superiors als 105 sous, segons l'estudi de Ramón Ferrer Navarro, La Plana: su estructura demográfica en el siglo XV, "Cuadernos de Historia», 5 (1975), pp. 67-91.

${ }^{32}$ Max TURULl, Finances i fiscalitat municipals a Catalunya durant la Baixa Edat Mitjana, "L'Avenç», 139 (1990), pp. 60-65. Aquest article es troba inclòs en un dossier sobre la fiscalitat medieval a Catalunya coordinat per Manuel Sánchez.

33 Antonio Collantes DE TERÁN, Alfonso $X$ y los Reyes Católicos: La formación de las baciendas municipales, «En la España Medieval», 13 (1990), pp. 253-270.

${ }^{34}$ Bernard CHevalier, Fiscalité municipale et fiscalité d'Etat en France du XIVe a la fin $d u$ XVIe siècle. Deux systèmes liés et concurrents, "Genèse de l'État moderne. Prélèvement et redistribution», París, CNRS, 1987, pp. 137-151. 
de les fonts d'ingrés, les ciutats de la monarquia francesa també van haver de suportar un greu endeutament - provocat des de 1450 per les demandes de la corona- que acabaria per afonar-les en una crisi financera i les abocaria a una forta retallada de la seua autonomia municipal.

El País Valencià no fou aliè a aquestes tendències i la vila de Borriana n'és un bon exemple. Si atenem el cas de Castelló i d'altres municipis del regne, pot veure's que en l'origen de l'endeutament es troba sobretot la necessitat de respondre a les peticions extraordinàries del rei $\mathrm{i}$ de les corts, en definitiva de finançar el bastiment d'un Estat cada volta més autoritari. La impossibilitat de reunir amb rapidesa aquestes elevades sumes estimulava el mercat del crèdit públic, que beneficiava especialment els inversors -cavallers i rics burgesosresidents a València. Per als prohoms locals només quedaven les molles del festí censalista, però el control polític que exercien sobre el municipi els permetia eludir una bona part de l'esforç fiscal i desviar-lo sobre les espatlles dels sectors populars ". L'endeutament va conduir la vila a una veritable crisi fiscal que només podia intentar de resoldre amb l'ajuda de la corona. A canvi, els gestors municipals havien de sotmetre's a la supervisió dels oficials del rei. El cicle viciós de l'endeutament, doncs, tingué els seus beneficiaris: per al patriciat de València -almenys fins al moment de la crisi- havia constituît un atractiu negoci rendista. La corona, per la seua banda, havia aconseguit recursos per a finançar el seu poder $i$, arran la fallida del municipi, trobà una porta oberta per al seu intervencionisme polític. El procés, finalment, també havia costat el seu preu. Borriana esdevingué una vila amb un veïnat cada volta més escàs $\mathrm{i}$ empobrit, que encara hauria d'afrontar serioses dificultats financeres a mesura que s'acostaven els temps moderns.

35 Als Paisos Baixos, el $80 \%$ del ingressos municipals descansaven sobre el petit comerç i el transport, però la càrrega de l'endeutament públic també fou canalitzada pels grups dirigents sobre l'artesanat, vegeu de Wim BLOCKMANS. Finances publiques et inégalité sociale dans les Pays-Bas aux XIVe-XVle siècles, "Genèse de l'État moderne...n, op. cit., pp. 7790. 


\section{APÈNDIX}

Creditors censalistes (1449-1456)*

\begin{tabular}{lccc}
\multicolumn{1}{c}{ nom } & ofici & lloc & pensions \\
Abat, Martí & botiguer & València & 250 \\
Alçamora (viuda de Bernat Forés) & notari & València & 1.225 \\
Alegre, Vicent & ciutadà & València & 1.375 \\
Alquècer, Llorenç & & Castelló & 210 \\
Andreu, Berenguer & & València & 675 \\
Arrufat, Miquel & mercader & Castelló & 1.575 \\
Baler, Francesc & & València & 175 \\
Belluga, Pere & jurista & València & 250 \\
Calataiú, Lluís de & noble & València & 727 \\
Castelló, Francesc & notari & Nules & 1.800 \\
Castelló, Guillem & & Borriana & 330 \\
Cavaller, Pere & prevere & València & 150 \\
Centelles, Pere & cavaller & Morvedre & 75 \\
Despont, Constança (filla de Gerard) & notari & València & 850 \\
Despuig, Joan & ciutadà & València & $562 / 6$ \\
Desvalls, Gràcia (muller de Galceran) & & València & 175 \\
Erau, Jaume (àlias Folch) & mercader & València & 500 \\
Esperandéu, Roger & pintor & València & 175 \\
Esteve, Francesc & mercader & València & 355 \\
Fabra, Pere & cavaller & València & 1.225 \\
Fenoll, Guillem & notari & Borriana & 165 \\
Ferrer, Pere & draper & València & 175 \\
Gaçó, Margarida (viuda de Lluís) & notari & València & 2.006 \\
Gamiça, Galceran & notari & València & 1.225 \\
Julià, Jaume & ciutadà & València & $3.874 / 2$ \\
Julià, Miquel & cavaller & València & $1.256 / 2$ \\
& & &
\end{tabular}

* Falten les dades referents als anys fiscals $1452-1453$ i $1453-1454$. 


$\begin{array}{lccc} & \text { ofici } & \text { lloc } & \text { pensions } \\ \text { Julià, Pere } & \text { ciutadà } & \text { València } & 574 \\ \text { Llopis, Manuel } & \text { pintor } & \text { València } & 1.507 \\ \text { Mir, Miquel } & & \text { València } & 170 \\ \text { Miralles, Pere } & \text { jurista } & \text { Castelló } & 1.215 \\ \text { Natera, Francesc de } & \text { donzell } & \text { València } & 500 \\ \text { Portaceli, Monestir de } & & & 3.500 \\ \text { Quintavall, Joan de } & & \text { València } & 175 \\ \text { Ros d'Orsins, Joan } & \text { donzell } & \text { València } & 1.750 \\ \text { Rubau, Bartomeu } & \text { donzell } & \text { Morvedre } & 150 \\ \text { Saburgada, Miquel } & \text { jurista } & \text { València } & 525 \\ \text { Saera, Elionor (viuda de Bernat Suau) } & \text { ciutadà } & \text { València } & 3.160 \\ \text { Saranyó, Isabel (muller de Pere) } & \text { donzell } & \text { València } & 550 \\ \text { Saranyó, Pere } & \text { donzell } & \text { València } & 1.812 / 6 \\ \text { Sorita, Nicolau } & \text { prevere } & \text { Borriana } & 375 \\ \text { Subirats, Marmessoria de Na } & & \text { Borriana } & 70 \\ \text { Súnyer, Bartomeu } & \text { prevere } & \text { Nules } & 750 \\ \text { Tarragó, Francesca (viuda de Miquel) } & \text { notari } & \text { Borriana } & 110 \\ \text { Torres, Antoni } & \text { jurista } & \text { València } & 350 \\ \text { València, Seu de } & & \text { València } & 562 / 6 \\ \text { Vera, Joan de } & & \text { Borriana } & 140 \\ \text { Vilanova, Antoni de } & \text { donzell } & \text { València } & 700 \\ \text { Vilanova, Pere } & & & 100 \\ \text { Vilarroig, Jofré de } & & & 41.410 / 10 \\ \text { Total } & \text { noble } & \text { València } & \end{array}$

\section{RÉSUMÉ}

En se basant sur le cas de Borriana, nous pouvons connaître les difficultés fiscales que traversaient, durant le $\mathrm{XV}^{\text {eme }}$ siècle, les principales villes royales du Pays Valencien. Bien que possédant des ressources fiscales importantes qui dépassaient beaucoup les revenus ordinaires que la couronne percevait dans la ville même, l'économie locale se voyait étouffée par un endettement accablant qui bénéficiait surtout les percepteurs d'impôts de la capitale du règne.

Au milieu du $\mathrm{XV}^{\mathrm{eme}}$ siècle, l'insolvabilité municipale motiva l'intervention de la couronne, qui finança un projet ambitieux d'assainissement économique. En échange de cette aide, le municipe dût céder une part de son autonomie et soumettre sa gestion financière au contrôle d'une bureaucratie royale centralisée. Finale- 
ment, le redressement eut un succès relatif au niveau macroéconomique, mais l'effort fiscal contribua à appauvrir la population et aggrava le déclin démographique de la ville.

\section{SUMMARY}

We have taken, as a base of our study, the case of Borriana to analyze the fiscal difficulties that suffered, during the $\mathrm{XV}^{\text {th }}$ century, the main royal towns of Valencian counties. Even if they had important fiscal receipts, that were much higher than the ordinary receipts that the crown collected in the mentioned cities, the local economy was mainly overburdened with debts that were highly favourable to tax collectors from the reign main cities.

By the middle of the $\mathrm{XV}^{\text {th }}$ century, the municipal insolvency motivated the intervention of the crown who financed an ambitious project of economic rehabilitation. In return for this aid, the councils were obliged to give up part of their autonomy and to submit their financial management to the control of a centralised royal bureaucracy. In fact, even if the rehabilitation was partially successful on a macroeconomic level, the fiscal efforts contributed to impoverish the population and to worsen the demographic decline of the cities. 